\title{
A LEI 11.645/2008 OU LEI ARACY LOPES DA SILVA: UM OLHAR DECOLONIAL PARA OS POVOS INDÍGENAS, A EDUCAÇÃO CRÍTICA E A FORMAÇÃO DOCENTE
}

JOSÉLIA GOMES NEVES ${ }^{1}$

UNIR, BRASIL

http://orcid.org/0000-0003-2318-5397

\begin{abstract}
RESUMO: Mais uma vez a temporalidade obscurantista visita o Brasil e com ela a violência autorizada, banalizada e naturalizada atinge duramente os Povos Originários brasileiros. Diante das interpelações da barbárie colonial e capitalista, nos resta a produção do conhecimento. Assim o estudo em tela de caráter qualitativo, discute as contribuições de Aracy Lopes da Silva e a Lei 11.645/2008. Esta norma trata da inserção do estudo da História e culturas indígenas no currículo. Os procedimentos metodológicos adotados consideraram a pesquisa bibliográfica, documental e narrativa. Os resultados informam que em 1970 indigenas e indigenistas questionaram as representações equivocadas sobre os índios na sociedade nacional e suas escolas. Essa inquietação mobilizou Aracy Lopes da Silva a propor em 1984 a temática indígena na escola, discussão posteriormente ampliada. (LOPES DA SILVA, 1987; LOPES DA SILVA; GRUPIONI, 1995). Concluimos que estas ações produziram desdobramentos significativos, como a publicação da Lei 11.645/2008 que repercute como política pública ancorada na perspectiva da Educação Crítica (FREIRE, 1987), Currículo Intercultural (NEVES, 2013) e Pedagogia Decolonial (WALSH, 2009). Uma episteme a favor dos indigenas e de suas diferenças.
\end{abstract}

PALAVRAS-CHAVE: Aracy Lopes da Silva, Antropologia Etnopedagógica, Lei 11.645/2008.

ABSTRACT: Once again the obscurantist temporality visits Brazil and with it the authorized, trivialized and naturalized violence hits hard the Brazilian Native Peoples. Faced with the challenges of colonial and capitalist barbarism, we are left with the production of knowledge. Thus the qualitative screen study discusses the contributions of Aracy Lopes da Silva and Law 11,645 / 2008. This standard deals with the insertion of the study of history and indigenous cultures in the curriculum. The methodological procedures adopted considered the bibliographical, documentary and narrative research. The results inform that in 1970 indigenous and indigenous peoplequestioned the misrepresentations about the Indians in the national society and their schools. This concern prompted Aracy Lopes da Silva to propose in 1984 the indigenous theme at school, a discussion that was later expanded. (LOPES DA SILVA, 1987; LOPES DA SILVA; GRUPIONI, 1995). We conclude that these actions produced significant developments, such as the publication of Law 11,645 / 2008 that has repercussions as a public policy anchored in the perspective of Critical Education (FREIRE, 1987), Intercultural Curriculum (NEVES, 2013) and Decolonial Pedagogy (WALSH, 2009). An episteme in favor of the indigenous and their differences.

KEYWORDS: Aracy Lopes da Silva, Ethnopedagogical Anthropology, Law 11,645 /2008.

\footnotetext{
${ }^{1}$ Doutora em Educação Escolar - UNESP/Campus de Araraquara. Professora da Universidade Federal de Rondônia no curso de Licenciatura em Educação Básica Intercultural - Departamento de Educação Intercultural (DEINTER). Programa de Pós-Graduação em Educação Escolar - Mestrado e Doutorado Profissional. Líder do Grupo de Pesquisa em Educação na Amazônia (GPEA). E-mail: joseliagomesneves@gmail.com
} 


\section{Contextualização}

Toda uma gama de teorias críticas contemporâneas sugere que é com aqueles que sofreram 0 sentenciamento da história - subjugação, dominação, diáspora, deslocamento - que aprendemos nossas lições mais duradouras de vida e de pensamento. Há mesmo uma convicção crescente de que a experiência afetiva da marginalidade social - como ela emerge em formas culturais não-canônicas - transforma nossas estratégias críticas (BHABHA, 1998, p. 240).

Este ensaio foi elaborado a partir de sentimentos de perplexidades, sensação de reedição do horror, mas também de esperança. Em 2015 ouvimos de um parlamentar federal a nefasta afirmação que: "Os índios não falam nossa língua, não têm dinheiro, não têm cultura. São povos nativos. Como eles conseguem ter $13 \%$ do território nacional ?"2.

Três anos depois este deputado foi eleito Presidente da República: Jair Bolsonaro. Em agosto de 2019, do Palácio do Planalto, reafirmou seus planos de exclusão dos interesses indígenas: "Enquanto eu for presidente, não tem demarcação de terra indígena"3.

Mas em janeiro, dias depois de sua posse, agravou-se drasticamente a invasão nos territórios indígenas. Elementos como esse permitem afirmar que há uma autorização em curso para uma violenta revisão das Terras Indígenas ( $\mathrm{Tl})$ no Brasil. No contexto da democracia representativa, o atual chefe do poder executivo fala e age como representante de forças ultraconservadoras.

Especificamente, no estado de Rondônia os Karipuna e Uru Eu Wau Wau têm sofrido diversos e continuados ataques em seus territórios comandados por emissários da grilagem, latifúndio e agronegócio em busca de extração de madeira, loteamento ilegal e exploração garimpeira. O sinal mais aterrorizador que vimos foi a perfuração à bala na placa da Terra Indígena Uru Eu Wau Wau - uma evidente intimidação de terror aos índios.

Um ataque que mobiliza muitas interpretações. A imagem da placa alvejada de balas é metafórica, inquietante e desestabilizadora. Talvez queira dizer que a pactuação estabelecida na Constituição Federal de 1988 com os Povos Indígenas, quanto à defesa de seus territórios, está seriamente ameaçada.

Recebi essa imagem e muitas outras, além de audiovisuais, por meio da rede social whatsApp, enviadas por estudantes indígenas que cursam a Licenciatura em Educação Básica Intercultural na Universidade

\footnotetext{
2 BOLSONARO diz que OAB só defende bandido e reserva indígena é um crime. Campo Grande, 22.04.2015. Disponível em: https://www.campograndenews.com.br/politica/bolsonaro-diz-que-oab-sodefende-bandido-e-reserva-indigena-e-um-crime Acesso em: 12 dez. 2019.

${ }^{3}$ BOLSONARO: "Enquanto eu for presidente, não tem demarcação de terra indígena" Carta Capital. 16.08.2019. Disponível em: https://www.cartacapital.com.br/politica// Acesso em: 21 dez. 2019.
} 
Federal de Rondônia (UNIR) em Ji-Paraná, Rondônia, graduação em que atuamos.

Figura 1 - Terra protegida?

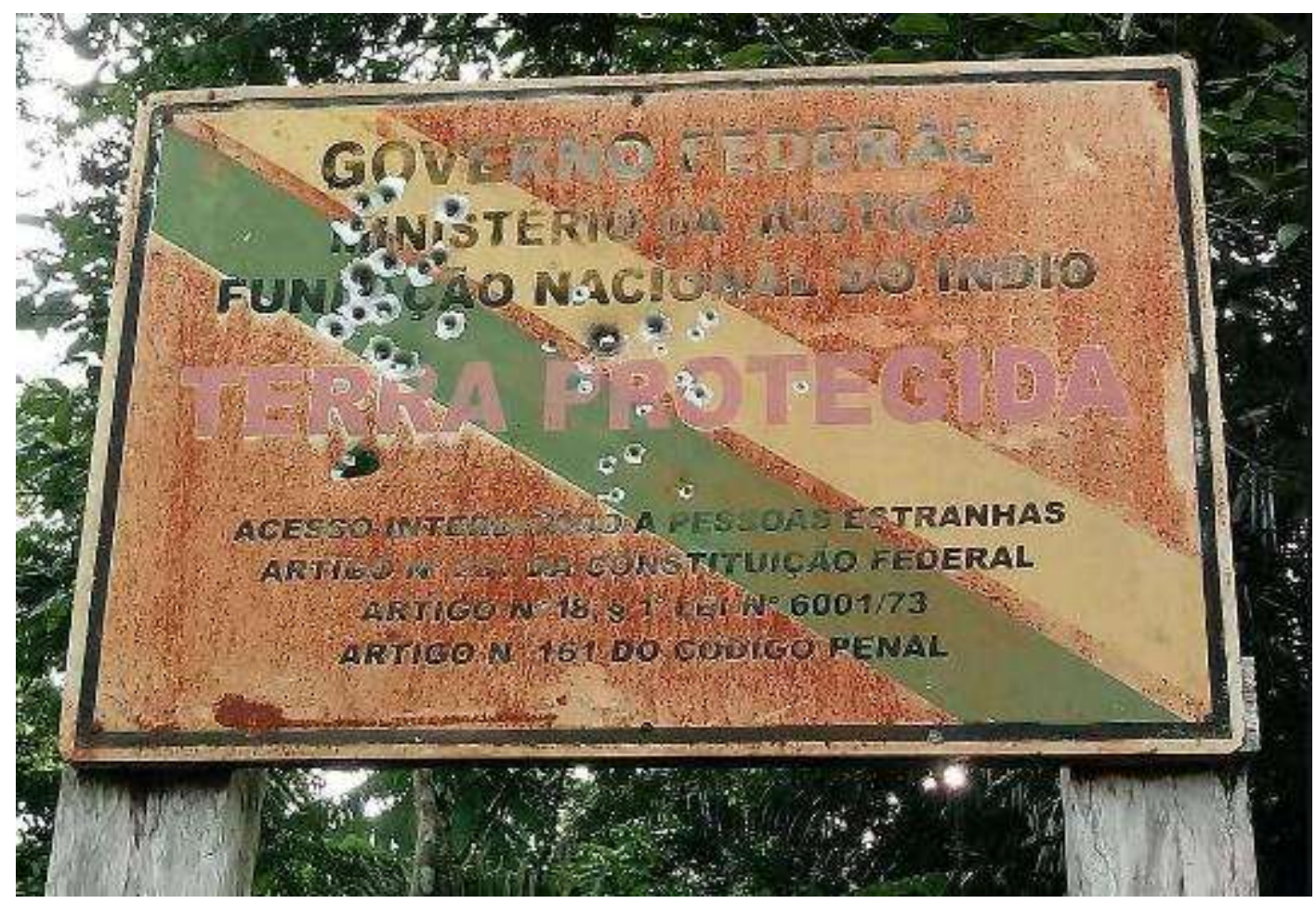

Fonte: Estudante Indígena Uru Eu Wau Wau (2019)

Eram pedidos de socorro e denúncias. Informavam sobre a entrada de grandes grupos de grileiros em seus territórios ${ }^{4}$ com fotos de derrubadas no interior da floresta, vestígios de acampamentos, ameaças dos invasores nas cidades vizinhas, dentre outras. Naquele momento o que foi possível fazer foi gritar ao mundo, divulgar a violência oficializada.

Por isso traduzimos esse momento como uma possível reedição do período ditatorial, quando as pactuações sociais foram desconsideradas e a democracia agonizou. Neste contexto, uma contribuição possível passa pela atualização do protesto, da construção da re-existência, que significa "vivir en condiciones 'otras', es decir en procesos de adaptación a un medio hostil en diversos sentidos y a un poder colonial que intentaba a toda costa reducirlos y mantenerlos en su condición de 'cosas' y/o mercancias" (ACHINTE, 2012, p. 30). E um desses jeitos é por meio da elaboração de escritas que falem por nós, pois: "Aprender a dizer a sua palavra é toda a pedagogia, e também toda a antropologia". (FIORI, 1987, p. 12).

Um pensar latino-americano mobilizado a partir de nossos problemas e perspectivas de enfrentamentos que mobilize para a

\footnotetext{
${ }^{4}$ Posseiros armados invadem Terras Indígenas em Rondônia dizendo que "Agora Bolsonaro é presidente" - Época. 30/01/2019. Disponível em: https://epoca.globo.com/guilherme-amado/posseiros-armadosinvadem-terras-indigenas-em-rondonia-dizendo-que-agora-bolsonaro-presidente-23415513 Acesso em: 24 dez. 2019.
} 
produção de epistemes "disruptivas de las que resultan emergiendo formas criticas de pensamento". (ACHINTE, 2012, p. 26). Neste sentido, avalio que a temática indígena significou uma episteme perturbadora na medida em que apresentou elementos de tensionamento ao currículo escolar. Em tempos de Parâmetros Curriculares Nacionais (PCN) da gestão tucana, representou uma crítica contundente ao documento "bonzinho" identificado como Pluralidade Cultural.

Assim, aprender e reaprender a temática indígena por meio da iniciativa de Aracy Lopes da Silva constitui um tempo para ver e ver de forma nova, novamente, seu trabalho militante e solidário. No dizer de Paulo Freire (1997), amorosidade para com os Povos Originários e um jeito de dizer que a professora faz falta: "Aracy deixa em nós uma imensa e profunda saudade, um sentimento de desalento diante de sua abrupta ausência, uma sensação de perda e de vazio. Por ser tão doce e cheia de vida, não posso deixar de pensar que ela partiu cedo demais". (GRUPIONI, 2000, p. 20).

A leitura de seu trabalho (LOPES DA SILVA, 1984) foi se estabelecendo como um diálogo enriquecedor com detalhes de um tempo em que o país se encontrava em uma fase de reconstrução de sua frágil democracia. Talvez esse contexto de esperança possa ter mobilizado suas ações para criar coletivos e assim possibilitar que um pequeno grupo de aliados (as) ousasse aprender e ensinar como discutir as sociedades indígenas na escola básica, um gesto de:

\begin{abstract}
Superar distâncias e incompreensões entre porções únicas e originais da humanidade; conhecer as razões, as noções e os estilos de outros povos, de outros mundos; abrir-se para a diversidade e o dinamismo com que a humanidade (que, apesar de ser sempre a mesma, é única) ricamente se apresenta, deixando-se maravilhar por eles, é lançar-se na aventura fascinante da descoberta de novos caminhos para o diálogo entre diferentes modos de ser, viver e pensar (LOPES DA SILVA e GRUPIONI, 1995, p. 320).
\end{abstract}

Essa escrita é endereçada a Aracy Lopes da Silva, quase que uma carta para comunicar, atualizar aspectos desta discussão. Um sentimento de alguém que também aprendeu com ela: "introduzidos à Antropologia pelas mãos de Aracy, trazemos vivas as suas lembranças como professora que conseguia ser generosa, acolhedora, aberta e, ao mesmo tempo, rigorosa e exigente". (TASSINARI, 2003, p. 337).

É também um olhar para a trajetória percorrida, o que permite fazer um balanço a respeito da relação educação e Povos Indígenas nos currículos das escolas brasileiras, inaugurado pela saudosa professora, sim, "A pedagogia aceita a sugestão da antropologia: impõe-se pensar e viver 'a educação como prática da liberdade"” (FIORI, 1987, p. 12). 
Figura 2 - Aracy e a questão/temática indígena na sala de aula.
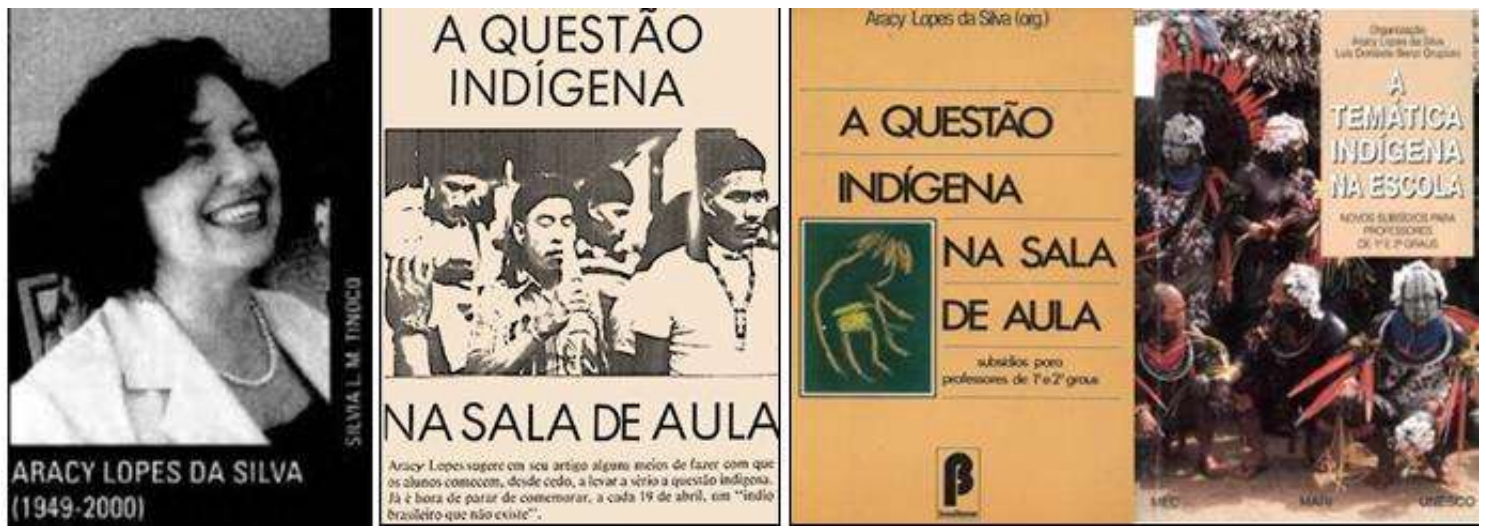

Fonte: Armazém Memória; Lopes da Silva (1984); Biblioteca C. Nimuendajú; Arquivos GPEA.

E nestes "dias desleais", no dizer da Legião Urbana (1991), verso da canção Metal contra as nuvens, o que nos resta é buscar nossas referências formativas. Daí o interesse de dialogar com os escritos de Aracy Lopes da Silva, reiterando o artigo "A questão indígena na sala de aula" (LOPES DA SILVA, 1984), que posteriormente fez parte de um trabalho ainda maior e coletivo, A Questão Indígena na Sala de Aula: subsídios para professores de $1^{\circ}$ e $2^{\circ}$ graus (LOPES DA SILVA, 1987) e continuou se expandindo em A Temática Indígena na Escola: novos subsídios para professores de $1^{\circ}$ e $2^{\circ}$ graus. (LOPES DA SILVA; GRUPIONI, 1995).

Deste modo, o estudo ora apresentado faz parte do Projeto de Pesquisa: Investigações crítico-decoloniais: o estudo da História e Culturas Indígenas - Lei 11645/2008. Um de seus objetivos é analisar as contribuições de Aracy Lopes da Silva e da Lei 11.645/2008. Para alcançar este intento, adotamos os recursos metodológicos da pesquisa documental e pesquisa narrativa (CUNHA, 1997). Os documentos são importantes fontes primárias de coleta de dados (LAKATOS; MARCONI, 1990). Os materiais utilizados nesta reflexão foram imagens e textos oriundos de arquivos digitais públicos ${ }^{5}$ relacionados aos trabalhos de Aracy, da Lei $11.645 / 2008$ e suas repercussões.

A pesquisa narrativa permitiu a inserção das concepções e experiências da pesquisadora, considerando as interpelações provocadas pela leitura dos escritos de Aracy e as vivências e percepções referentes à Lei 11.645/2008. Este procedimento constitui um recurso valioso e decolonial por permitir o "reconhecimento e a reflexão do sujeito sobre si mesmo para melhor reconhecer-se como profissional educador" (CUNHA, 1997, p. 8).

A investigação se caracteriza como qualitativa (BOGDAN; BIKLEN, 1994), por envolver um processo descritivo e analítico da relação entre a antropóloga Aracy e a Lei 11.645/2008, tendo por eixo central os significados atribuídos pela pesquisadora na interpretação do objeto. 
Assim, ler Aracy é retomar e reviver inspirações. É reavaliar a proposição feita em 2013 no Projeto de Pesquisa: História e cultura indígena como conteúdos de aprendizagem: como anda a implementação da Lei $11.645 / 2008$ nas escolas públicas da Amazônia? Uma proposta investigativa que surgiu a partir de inquietações provocadas em minhas vivências com os Povos Indígenas de Rondônia, com a referida Lei e principalmente em função de seus trabalhos sobre a questão/temática indígena em sala de aula, momento memorável em que "a pedagogia [fezse] faz-se antropologia" (FIORI, 1987, p. 7).

\title{
Os Povos Indígenas nas escolas da "sociedade nacional": o pensamento pedagógico-decolonial de Aracy Lopes da Silva.
}

\begin{abstract}
Tem sido, $[\ldots]$, cada vez mais difícil comemorar o Dia do Índio. A situação dramática que as populações indígenas vêm vivendo no Brasil faz com que as celebrações do dia que lhes é dedicado se transformem em oportunidade para denúncias $[\ldots]$. Há o lado político (e humano) da questão: os problemas enfrentados hoje pelos índios ameaçam sua sobrevivência. E por ela é preciso lutar. Por ela é preciso organizar-se e encontrar aliados na sociedade nacional (LOPES DA SILVA, 1984, p. 48).
\end{abstract}

A epígrafe suscita muitas reflexões. Soa quase como um desespero. A contradição da "comemoração" aos Povos Indígenas diante de um quadro de realidade brutal de ataque aos seus territórios e a suas diversas formas de viver, causava perplexidade. Diante disso o que restou foi à busca por justiça curricular, uma concepção que busca:

\begin{abstract}
"Comprometer-se com uma educação crítica e libertadora obriga a investigar em que medida os objetivos, os conteúdos, os materiais curriculares, [...] respeitam as necessidades dos distintos grupos sociais que convivem em cada sociedade" (SANTOMÉ, 2013, p. 9).
\end{abstract}

Essa disparidade entre a festividade e uma ação adequada em contexto escolar produziu muitos desdobramentos entre a Antropologia e a Pedagogia. Uma Pedagogia Decolonial, compreendida como: "processo e prática sociopolíticos produtivos e transformadores assentados nas realidades, subjetividades, histórias e lutas das pessoas, vividas num mundo regido pela estrutura colonial" (WALSH, 2009, p. 26).

Possivelmente Aracy Lopes da Silva percebeu também a lógica que mobilizou o pensamento freireano ao longo da vida do educador pernambucano, que no processo formativo existe a possibilidade da mudança, porque se por um lado: "a educação nem é uma força imbatível a serviço da transformação da sociedade, [...] tampouco é a perpetuação do 'status quo' porque o dominante o decrete". (FREIRE, 1987, p. 68). É a Educação crítica que sustenta que nossa incompletude exige 
permanentes processos de aprendizagem que se materializam através da formação permanente na busca da humanização.

A professora Aracy compreendeu que era preciso pensar alternativas curriculares para além do dia 19 de abril, de modo que a escola pudesse subverter a rotina da "comemoração" elaborando possibilidades críticas que permitissem conhecer e denunciar os horrores a que as nações indígenas ${ }^{6}$ estavam sendo submetidas.

A proposta de intervir no formato escolar teve como principal argumento político a pauta da vida, defesa central dos direitos humanos - a existência indígena se encontrava em perigo. $O$ espaço de aprender e lutar não se limitava à sala de aula: "além das atividades didáticas, acadêmicas e administrativas na Universidade, participou durante vários anos da luta pela causa indígena, defendendo os direitos dos índios, suas terras, suas línguas e culturas" (VIDAL, 2000, p. 14).

É possível vislumbrar a visão humanista de Aracy ao propor o estudo da questão indígena no ambiente escolar. A antropólogaeducadora traduzia os diferentes problemas enfrentados pelas sociedades originárias no termo "questão". Analiso que, com essa construção, ela tomava para si a responsabilidade de fazer algo a respeito como cidadã, como alguém que se vê no mundo com outras pessoas, que entendia que viver bem é direito de todos e todas:

\begin{abstract}
A questão indígena está longe de ser um "problema dos índios", portanto ela diz respeito a todos nós. Cabe a todos nós decidirmos se queremos uma nação justa e respeitosa dos direitos das pessoas. Cabe a nós todos pensarmos um momento sobre a riqueza de experiências humanas de que desfruta um país que respeitar as diferenças culturais e se construir através de modos mais simétricos de relacionamento entre seus muitos segmentos (LOPES DA SILVA, 1984, p. 50).
\end{abstract}

Deste modo, no trabalho de 1984, a antropóloga argumenta que a "comemoração" referente ao "dia do índio" para ser efetiva deveria contemplar três eixos orientadores: dispor de informações confiáveis sobre as culturas indígenas e suas concepções de vida, produzir um diagnóstico preciso sobre as problemáticas enfrentadas pelos indígenas, principalmente no que diz respeito às invasões em seus territórios, e se dispor a rever e romper com a visão equivocada sobre os indígenas, em suas feições polares de idealização ou discriminação.

Observou que a relação do Estado brasileiro com as nações indígenas se caracterizava pela manutenção das práticas coloniais, expressas nas medidas oficiais em seus modelos autoritários e assistencialistas. Práticas que de algum modo se estendiam e se reproduziam no cotidiano pelo cidadão ou cidadã comum. Diante disso,

\footnotetext{
${ }^{6}$ Tenho retomado o uso do termo nações indígenas, tendo em vista que em minha avaliação o sistema de sustentação do modo de vida das sociedades indígenas, mesmo em tempos de globalização, mantém elementos importantes e independentes das macrossociedades.
} 
indagava: "O que a Antropologia teria a ensinar a esse respeito, enquanto ciência voltada à descoberta do outro, ao estudo de culturas, as mais diversas, em seus próprios termos?" (LOPES DA SILVA, 1984, p. 48).

Defendia a importância de todas as experiências possibilitadas por diferentes humanidades: "Cada povo e cada cultura atualiza uma das formas possíveis de humanidade. São modos alternativos de 'ser gente'. A exigência maior, [...] entre representantes de culturas diversas, é o esforço pelo relacionamento simétrico" (LOPES DA SILVA, 1984, p. 48). O livro didático negava essa complexidade:

Figura 3 - Imagens do livro didático e estereótipos sobre os Povos Indígenas.

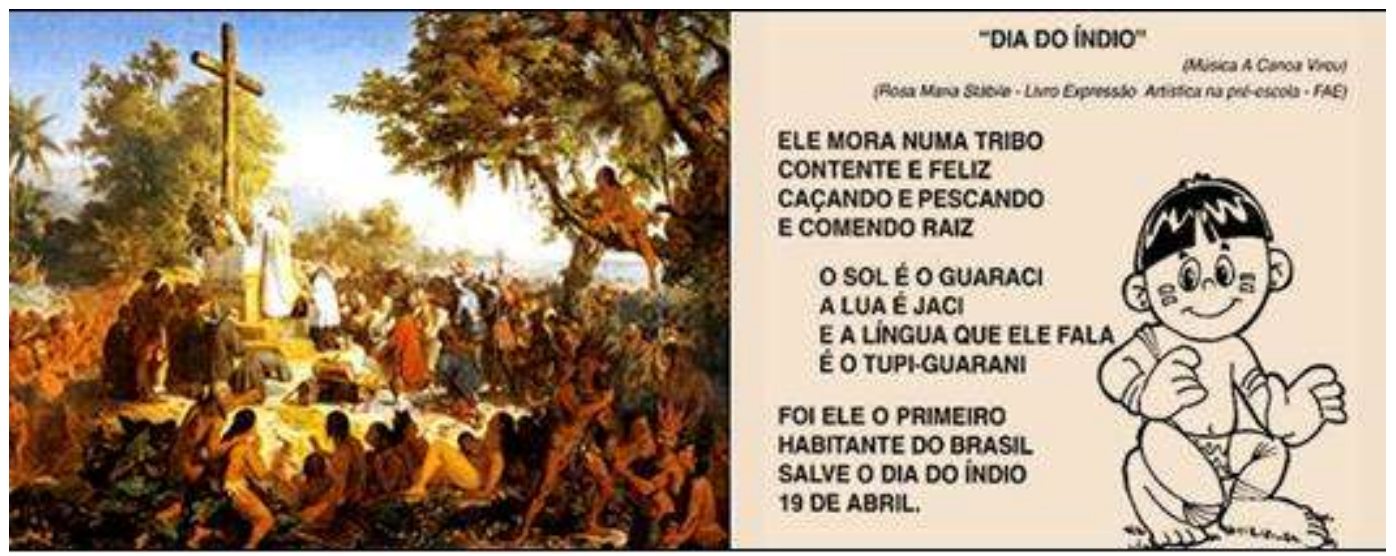

Victor Meirelles (1861) e Rosa M. Stábile - Expressão Artística na Pré-Escola- FAE

Aracy criticou o etnocentrismo da dita "sociedade nacional" e viu nas diferenças culturais elementos importantes para a pauta curricular e as relações entre o pensamento antropológico e pedagógico por meio da crítica ao livro didático. A autora questionou a concepção universalista que reduzia as populações indígenas a uma única representação étnica, informando a existência na época de 150 (cento e cinquenta) povos, falantes de 100 (cem) línguas. Em uma linguagem sintetizada e acessível, apresentou de forma exuberante um panorama que expressava um mundo até então pouco conhecido pelos (as) educadores (as):

Cada um com seu próprio estilo de vida, sua maneira de organizar suas relações com a natureza e as relações entre os seus membros; cada um com a sua própria visão de mundo, com seus mitos, seus rituais, sua cosmologia. Há povos caçadores e coletores; há povos agricultores e pescadores. Há sociedades organizadas em aldeias muito numerosas; há povos que vivem em grupos pequenos; há os sedentários e há os seminômades. Os modos de adaptação ecológica são variados, assim como as experiências históricas de cada povo são únicas (LOPES DA SILVA, 1984, p. 48).

Aracy questionou os conteúdos veiculados pelo livro didático, indagando: como um conjunto de palavras como oca, taba, pajé, Tupã, 
dentre outras, possivelmente retiradas de contextos de sociedades do período da chegada dos europeus, poderiam resumir os modos de vida de tantas etnias? Essa mentalidade resultou na concepção equivocada de um índio universal, fragmentado, desatualizado, desfocado, cuja imagem era/é veiculada na sala de aula.

Aliada significativa dos Povos Indígenas, Aracy compreendeu que era urgente pensar e materializar meios de enfrentamento ao não saber. E uma dessas formas viria por meio da educação formal - a escola, uma das instituições da chamada sociedade nacional, que foi convocada a conhecer as etnias brasileiras: "quem são, afinal, estes índios, cujo dia as escolas devem festejar? Como vivem, que línguas falam, qual o seu futuro? O que sabemos nós a seu respeito? O que queremos nós que nossos alunos pensem sobre eles?" (LOPES DA SILVA, 1984, p. 48).

A autora chama a atenção para as diferentes respostas construídas pelos indígenas em relação aos locais de suas moradias na floresta ou cerrado, bem como dos conhecimentos linguísticos variados, sistematizados em quatro troncos: Tupi-Guarani, Macro-jê, Aruak e Caribe, tema apresentado de forma primorosa na publicação ampliada:

A língua é também a chave que nos permite conhecer todo o universo cultural de um povo. A cultura de um povo é nada mais nada menos que o conjunto das respostas que aquele povo dá às experiências pelas quais ele passa e aos desafios que ele sofre. A língua, bem como a cultura, vão sendo moldadas ao longo do tempo. [...]. O conhecimento das línguas indígenas e, através delas, o conhecimento da experiência e do conhecimento acumulados pelos povos que as falam é de valor cultural e social inestimáveis (TEIXEIRA, 1995, p. 293).

Em relação aos aspectos sociais, aponta aproximações entre os povos da época, tais como: território como elemento comum, a distribuição dos alimentos, a divisão sexual do trabalho a partir de idade e gênero, destaca o funcionamento do sistema de obrigações que define as tarefas dos membros, a relação de parentesco e o processo do aprender e ensinar, com destaque para os mais velhos, conhecedores e referências da experiência coletiva.

Sobre a Fundação Nacional do Índio (FUNAI), analisou as falhas do órgão indigenista, considerando os posicionamentos de lideranças e representantes quanto ao trabalho desenvolvido: "a acusação mais recorrente é a de infidelidade: ao invés de agir em defesa dos direitos constitucionais dos índios, a FUNAl tem muitas vezes sucumbido a pressões de toda ordem e tomado atitudes contrárias" (LOPES DA SILVA, 1984, p. 50). Ao avaliar as fragilidades, inações e contradições da FUNAI, concluiu que seu compromisso principal não era com os índios e sim com o governo, que respondia e servia muito mais aos interesses governamentais que as sociedades indígenas. 
Avalio que na gestão dos governos petistas, entre 2003 e meados de 2016, houve um tensionamento para que a FUNAI levasse em conta os interesses indígenas, por meio de investimento em sua estrutura física e pessoal. No entanto, desde o golpe político de 2016 que resultou no afastamento da presidenta Dilma Rouseff, essa instituição encontra-se instável, esvaziada, neutralizada e amordaçada.

Já houve uma enxurrada de exonerações de quadros qualificados de áreas importantes como demarcação de Terras Indígenas e Índios Isolados. Existe, como em todo o país, um movimento de caça às bruxas na instituição em busca de perfis de "esquerda" - supostos "petistas" ou "comunistas". Dentre os nomes de substituição, há suspeitas de indígenas indicados pelo agronegócio, o que caracteriza uma relação intercultural de faz de conta, funcional, traduzida como um conjunto de "dispositivos de poder que permitem a permanência e o fortalecimento das estruturas sociais estabelecidas e sua matriz colonial" (WALSH, 2009, p. 13). Uma fachada de inclusão.

Outra questão destacada pela antropóloga há 36 (trinta e seis) anos atrás, foi a centralidade dos territórios indígenas. Afirmou as lutas constantes dos povos no que diz respeito à manutenção de suas terras. Nesta época listou as principais ameaças: exploração de minérios, projetos hidrelétricos, fazendas e estradas, e suas vinculações com a política estatal. O que mudou neste quadro pré-Constituição de 1988 ?

A organização do movimento através da União das Nações Indígenas (UNI) foi analisada por Aracy como uma possibilidade de luta em prol de seus interesses. Um meio de protagonizar suas demandas, denunciar as lacunas da FUNAI. A meu ver, a UNI atuou como um dispositivo para "arrancar" do Estado as politicas públicas que precisavam chegar até às aldeias:

En este espacio fronterizo de relación y negociación se construyen y emergen nuevos conocimientos sentidos, prácticas y acciones que desafían el poder-saber dominante y empiezan a filtrarse en él. Por eso, podemos hablar de un accionar epistémico, es decir, de un interculturalizar epistemológico que construye nuevos criterios de razón y verdad (epistèmes) y nuevas condiciones de saber que no pueden ser catalogadas estáticamente, y cuyos impactos y efectos están empezando a extenderse más allá de la esfera política. Se refiere a estos procesos y actividades del pensar que, como sus pensadores, se mueven entre lo local y lo global, entre el pasado (re- inventado) y el presente, y como movimiento étnico, social y político de oposición, entre varias especialidades y frentes (WALSH, 2012, p. 16).

Atualmente o movimento indígena é coordenado pela Articulação dos Povos Indígenas do Brasil (APIB), sob a liderança de uma mulher indígena, Sonia Guajajara. Isso não é pouca coisa. A entidade surgiu em 
2005, resultante de um desdobramento do Acampamento Terra Livre, mobilização politica anual que ocorre no mês de abril na capital federal.

Outros temas foram tratados no texto elaborado em 1984 e republicado três anos depois no livro: $A$ Questão Indígena na Sala de Aula: subsídios para professores de $1^{\circ}$ e $2^{\circ}$ graus (LOPES DA SILVA, 1987), uma importante coletânea. Produzida a muitas mãos, a mobilização central materializou uma revisão da imagem dos Povos Originários e da questão indígena reproduzida até então nos livros didáticos, endereçados à docência de $1^{\circ}$ e $2^{\circ}$ graus - atual ensino fundamental e médio.

O livro está dividido em duas partes: inicialmente apresenta um conjunto de críticas sobre as barbaridades existentes nos livros didáticos, tornando-se, assim, uma referência primária desta discussão temática. Inicialmente, em linguagem acadêmica, os textos dissecaram materiais da época e demonstraram por meio de imagens. Dentre outros pontos, os conteúdos apresentados ensinavam as crianças e jovens que os indígenas não existem mais, pois sua existência é narrada no contexto de 1500 - na atualidade não eram mais considerados.

A esse respeito, os Estudos Culturais disponibilizam ferramentas teóricas que apontam que as identidades sofrem alterações no decorrer dos processos históricos. Os indígenas de hoje não podem ser vistos como aqueles de antigamente em uma visão linear, pois: "A identidade torna-se uma 'celebração móvel': formada e transformada continuamente em relação às formas pelas quais somos representados ou interpelados nos sistemas culturais que nos rodeiam" (HALL, 2006, p. 12-13).

O outro objetivo do trabalho foi disponibilizar propostas com possibilidades de execução na sala de aula, considerando as ausências e equívocos percebidos nos materiais didáticos. Nesta direção, uma das autoras do livro informa: "Aracy Lopes da Silva contribui com um excelente, imprescindível mesmo, conjunto de informações [...] para orientar os textos e os professores, [...] para colocar a questão indígena na sala de aula" (TELLES, 1987, p. 80).

Esse material representou com maior desenvoltura um duro e necessário questionamento sobre um formador de mentes: o livro didático. Possivelmente tem relação com a repercussão dos trabalhos de Eco e Bonazzi (1980) Mentiras que parecem verdades, publicado em 1972 na Itália e As Belas Mentiras: a ideologia subjacente aos textos didáticos, de Nosella (1978), no Brasil, fruto de uma dissertação de mestrado. Ambos desenvolveram por meio da pesquisa documental, estudos sobre os livros didáticos a partir de temas semelhantes.

Mas foi apenas em 1995 que Aracy e Grupioni traduziram uma preocupação epistêmica ampla: a de produzir respostas mais contundentes como enfrentamento aos estereótipos, preconceitos e discriminações contra as sociedades indígenas brasileiras. Um livro de quase 600 (seiscentas) páginas marcava de forma significativa o currículo escolar em formato interdisciplinar e intercultural:

Aracy tinha como uma de suas preocupações a difusão de informações sobre as sociedades indígenas [...]. De 1992 a 1996, ela coordenou uma série de cursos de 
extensão universitária que o Mari ofereceu para professores da rede pública de São Paulo sobre a questão indígena no Brasil. Desse esforço de ampliar a divulgação de conhecimentos sobre os índios, nasceu $[\ldots]$ o livro $A$ temática indígena na escola, [...]. Lançado em 1995, este livro era uma versão ampliada e atualizada de [...] A questão indígena na sala de aula, 1987 (GRUPIONI, 2000, p. 19).

Durante 4 (quatro) anos, de forma mais intensa a pesquisadora aprendeu e ensinou com os professores e professoras das escolas públicas de São Paulo, trabalho formativo que se estendeu na sistematização do livro sobre como trabalhar pedagogicamente a temática indígena no contexto escolar: "A antropologia acaba por exigir e comandar uma política" (FIORI, 1987, p. 7).

Desde então não há mais desculpas para o não saber sobre os Povos Originários na escola. Como já mencionamos, Aracy e colaboradores (as) contribuíram com a justiça curricular, "resultado da análise do currículo que é elaborado, colocado em ação, avaliado e investigado levando em consideração [...] necessidades e urgências de todos os grupos sociais" (SANTOMÉ, 2013, p. 9).

Uma breve busca na internet confirma que na atualidade, a leitura do referido livro possibilita desdobramentos que contemplam diferentes campos do saber no âmbito da pesquisa, ensino e extensão universitária. Assim, a produção de conhecimentos decoloniais que foram elaborados em processos de reflexões e busca de respostas, possivelmente resultou em A temática indígena na escola, confirmando "a educação como intervenção" (FREIRE, 1987, p. 68). Embora a perspectiva de educação crítica possa ser interpretada ao longo do livro, não há nenhuma citação ou menção a Paulo Freire nas suas 561 páginas. Seria interessante uma escrita sobre isso.

\section{Aracy, a temática indígena e a Lei 1 1.645/2008: por uma Antropologia Etnopedagógica.}

Mais uma vez os homens [e as mulheres], desafiados pela dramaticidade da hora atual, se propõem, a si mesmos, como problema. Descobrem que pouco sabem de si, de seu "posto no cosmos", e se inquietam por saber mais. Estará, aliás, no reconhecimento do seu pouco saber de si uma das razões desta procura. Ao instalar-se na quase, senão trágica descoberta do seu pouco saber de si, se fazem problema a eles mesmos. Indagam. Respondem, e suas respostas os levam a novas perguntas. [...]. Constatar esta preocupação implica, indiscutivelmente, reconhecer a desumanização, [...]. É também, [...] a partir desta dolorosa constatação, [...] que se perguntam sobre a 
outra viabilidade - a de sua humanização (FREIRE, 1987, p. 19).

Recorro a esta epígrafe de Paulo Freire sempre que minhas respostas são insuficientes diante de um emaranhado de questões que a vida demanda. Implica pensar que a humanização pode ser viabilizada e ampliada pelo conhecer crítico, elemento relevante para a formação das pessoas. E na minha história de vida e profissional experimentei um pouco disso, foi numa época em que estava conhecendo pela primeira vez algumas etnias de Rondônia.

Compartilhando este momento comigo, um amigo me presenteou com o livro A Temática Indígena na Escola: novos subsídios para professores de $1^{\circ}$ e $2^{\circ}$ graus, em 2001 . Seus escritos diziam: "Jô, a beleza da vida está nas múltiplas possibilidades humanas de se viver. Este é pra você se aproximar ainda mais do indigenismo. Cris". Foi um presente especial do Cristovão Teixeira Abrantes, semelhante a uma "Felicidade clandestina" no dizer de Clarice Lispector (1998), porque embora quisesse me dedicar àquela leitura, as demandas profissionais me impediam.

Mas o encontro magistral com este livro ocorreu quando ingressei na Universidade Federal de Rondônia (UNIR), Campus de Ji-Paraná. Neste tempo, este imenso livro em todos os sentidos foi efetivamente "devorado". Inicialmente na disciplina Educação com os Povos da Floresta, ministrada no Curso de Pedagogia de 2004 a 2017, e depois no Grupo de Pesquisa em Educação na Amazônia (GPEA), especialmente com a criação da Linha de Pesquisa Antropologia Etnopedagógica e Currículo.

O trabalho desenvolvido na iniciação científica, por meio do projeto Lápis, caderno, flecha e preconceito no período 2011-2012, tinha como objetivo principal analisar as relações dos estudantes indígenas na escola urbana na perspectiva das crianças e seus familiares. Ali foi possível compreender que as práticas coloniais existentes na sociedade são reproduzidas de várias formas no ambiente escolar:

O estudo realizado permitiu aproximações com os sentimentos destas crianças na escola urbana, uma escola vista por elas como a escola do "branco", do outro, em função possivelmente do olhar que dirige a elas: ora de invisibilidade quanto as suas especificidades linguísticas e culturais, ora de discriminação explícita materializada por meio de apelidos, piadas, incompreensões sobre seus modos de vida e silenciamentos, práticas autorizadas talvez pela herança das antigas relações escravocratas e hierárquicas de mando, existentes nas fazendas e seringais, como a proibição de falar na língua materna, na atualidade repercutindo e ecoando manifestações do passado colonizador, o que nos autoriza a interpretar a presença indígena na escola urbana hoje como uma reedição do contato (NEVES, 2013, p. 19). 
Com o conhecimento desta situação, iniciei uma investigação mais aprofundada sobre a implementação da Lei $11.645 / 2008$ na rede escolar pública de Ji-Paraná, Rondônia. O objetivo era compreender se a referida normativa era conhecida, como a questão indígena era discutida nos cursos de formação docente e como se materializava no fazer pedagógico da educação básica.

As leituras sobre a presença indígena no currículo foram intensificadas por meio das Jornadas Pedagógicas - evento do Grupo de Pesquisa em Educação na Amazônia (GPEA) para a formação metodológica e teórica no âmbito da iniciação cientifica e da pós-graduação. Ali muitos textos do livro Temática Indígena foram lidos, relidos, discutidos com colegas docentes e estudantes indígenas e não indígenas: línguas, mitos, contribuições das culturas indígenas, livro didático, os equívocos quanto a compreensão dos territórios, dentre outros.

Como não ficar encantada com as lições da interculturalidade na leitura de A contribuição dos povos indígenas à cultura brasileira de Berta Ribeiro? Neste recorte de uma publicação anterior (RIBEIRO, 1984), a autora apresenta um conjunto de elementos a partir de diferentes etnias que fundamentam a síntese extraordinária das contribuições dos povos indígenas para que o Brasil fosse o que é hoje, e afirma que: "a dívida que a humanidade contraiu com o saber etnobotânico do primitivo habitante das Américas está longe de ser resgatada. As principais plantas de que se alimenta [...] a humanidade foram descobertas e domesticadas pelos ameríndios". (RIBEIRO, 1995, p. 119).

Difícil não se admirar com a ousada proposição de estudar o mito na sala de aula das escolas da "sociedade nacional", um contraponto à empobrecida leitura que se expressa nas chamadas lendas brasileiras: "Desconfio que um caminho possível seja desenvolver atividades de pesquisa específica, com os alunos, em que uma grande atenção seja dispensada à compreensão da sociedade de onde o texto mítico em exame provém, acompanhada por uma atitude de reflexão". (LOPES DA SILVA, 1995, p. 319).

Muitos outros aspectos poderiam ser destacados no livro, mas citamos apenas as ilustrações acima com vistas a estabelecer uma correspondência com a Lei $11.645 / 2008$ no que se refere tanto as contribuições dos Povos originários na formação do país como nas possibilidades de buscar saberes a partir de instrumentos conhecidos, tendo por base referências locais.

O conjunto de textos produzidos por profissionais credenciados sobre os Povos Originários representa na atualidade um acervo de qualidade excepcional para a docência na educação básica. Um material que veio antes da Lei 11.645/2008. Após quase 25 anos da publicação de A Temática Indígena na Escola: novos subsídios para professores de $1^{\circ}$ e $2^{\circ}$ graus, da Lei $11.645 / 2008$, a referida normativa foi sancionada (BRASIL, 2008). E depois de 7 (sete) anos, suas diretrizes operacionais foram viabilizadas por uma indígena responsável pela relatoria, o Parecer 14 (BRASIL, 2015).

Analiso que o advento destas publicações oficiais provocou uma procura muito grande deste material seja por docentes, pesquisadores 
(as) e até mesmo pelo mercado editorial para estudo. Uma fonte adequada para a orientação de atividades acerca da implementação da História e das culturas dos povos originários no currículo escolar. A versão digital e gratuita do livro certamente assegura um acesso inimaginável, outro acerto de Aracy quando viabilizou o material no formato público. Certamente há necessidade de atualização de dados demográficos e linguísticos na obra, considerando as mudanças culturais que inevitavelmente acontecem.

Mas do ponto de vista histórico, etnológico e intercultural, $A$ Temática Indígena na Escola: novos subsídios para professores de $1^{\circ}$ e $2^{\circ}$ graus ainda tem muito a dizer, a ensinar e a contribuir na revisão da imagem equivocada que povoa ainda muitas mentes em nosso país e impulsiona ações violentas sobre as identidades indígenas. Em função de suas omissões e/ou práticas coloniais, certamente a escola, além de outros atores sociais, têm responsabilidade nestas situações:

o assassinato de Galdino Pataxó, por quatro jovens brancos de classe média em 1997 em pleno mês de abril em Brasília, ocasião em que discutia problemáticas relacionadas a seu povo junto ao governo federal; Outra situação evidenciada neste sentido foi à divulgação por meio de outdoors no estado do Espírito Santo por grandes empresários ligados à produção de papel, o que explicita o poderio econômico em um debate de uma fala única, cuja frase expressava uma evidente defesa ao desenvolvimentismo: 'A Aracruz trouxe o progresso, a FUNAI os Índios' (NEVES, 2013b, p. 4).

No entanto, em meio a este contexto, há pequenos avanços potencializados pela Lei 11645/2008 e pelo Parecer 14 (BRASIL, 2008; 2012) no cenário educacional brasileiro, no que diz respeito às possibilidades de um maior conhecimento dos Povos Indígenas, provavelmente a curto, médio e longo prazo. De antemão, arrisco a pensar para além da normativa e vislumbro as possibilidades da efetivação de uma política pública, inferência elaborada no decorrer da realização de várias atividades acadêmicas.

Os diálogos realizados com Darci Secchi, docente da Universidade Federal do Mato Grosso (UFMT), por ocasião de bancas de qualificação ou defesa de mestrado, foram momentos de muitas aprendizagens. Contra meu otimismo acerca dos efeitos da Lei 11645/2008, o Professor Darci, desconfiado, recitava Drummond: "As leis não bastam. Os lírios não nascem da lei". (ANDRADE, 2000, p. 29). Um argumento que condenava a minha interlocução ao silêncio.

No entanto, meio como Fênix, eu cambaleante, retrucava. Entendo que um primeiro aspecto, a considerar é que a publicação da Lei 11.645/2008 legitimou uma trajetória histórica oriunda das lutas indígenas e indigenistas desde 1970 traduzidas no desconforto com a imagem veiculada na escola. E em função disso houve a necessidade de elaborar produtos educativos que permitissem um maior conhecimento 
das sociedades originárias: "Nós teríamos que mostrar à população que o índio tem seu modo próprio de viver", afirmação do antropólogo Silvio Coelho $^{7}$ proferida em 1977 no Seminário, "O Índio brasileiro: um sobrevivente?", evento que contava com a participação indígena Kaingang e Guarani. Preocupações como esta mobilizaram muitas ações formativas, dentre as quais, os trabalhos de Aracy.

Outro aspecto importante, o segundo da lista na minha visão, diz respeito aos bastidores legais que originaram a Lei $n^{0} 11.645$. Foi possível entender que a referida norma resultou de pressões indígenas e da articulação de parcerias parlamentares em 2003. Naquele ano, a Lei $n^{\circ}$ 10.639 havia sido sancionada, mas tratava exclusivamente da inserção do estudo da História da África, africanos, a luta, culturas e contribuições dos negros para a sociedade brasileira. Sobre a questão, a deputada federal Mariângela Duarte (PT), autora do Projeto de Lei (PL) $n^{\circ} 433$, registra a ausência de normativa para a questão indígena:

\begin{abstract}
A sociedade saudou, recentemente, a sanção presidencial à lei que tornou obrigatório o ensino de história e cultura afro-brasileira, nos estabelecimentos de ensino fundamental e médio, oficial e particular. Referida lei foi criticada, no entanto, pela comunidade indígena, que não foi contemplada com a previsão de disciplinas para os alunos conhecerem a realidade indígena do País (BRASIL, 2003, p. 2).
\end{abstract}

O primeiro despacho data de 7 (sete) de abril de 2004, passou pela relatoria feita pela Deputada Federal Fátima Bezerra (PT), cujo Parecer foi favorável (BRASIL, 2003). O processo tramitou até 26 de outubro de 2005 na Câmara dos Deputados. Nesta última data, foi remetido ao Senado onde contou com a análise da Senadora Fátima Cleide (PT), relatora do Parecer $n^{\circ} 22 / 2007$, aprovado. Além de reiterar a falha da Lei anterior, a lacuna dos Povos Indígenas, ressalta que o trabalho pedagógico pode contribuir no enfrentamento das discriminações:

ficou omitida a história e a cultura indígenas. É essa lacuna que o presente projeto de lei procura preencher, de forma a garantir o equilíbrio, nos estudos de história e cultura brasileiras nos ensinos fundamental e médio, entre as grandes etnias presentes na formação de nosso País, particularmente aquelas que tradicionalmente eram relegadas ao esquecimento e ainda são objeto de distorções e preconceitos (BRASIL, 2007, p. 3).

A última tramitação desta discussão foi na Comissão Diretora responsável pela redação final, momento em que foi registrado como

\footnotetext{
${ }^{7}$ Exploração e miséria. A cultura indígena acabando aos poucos. FM 29.04.1977. Armazém Memória. Coleção de recortes de jornal sobre a política indigenistalColeção CIMI-MS $\backslash 1977$. Disponível em: http://www.docvirt.com/docreader.net/DocReader.aspx?bib=HemeroIndioRecortes\&pesq=coelho Acesso em: 22 dez. 2019.
} 
Parecer $n^{0} 1.257$ em dezembro de 2007, posteriormente foi transformada em norma jurídica e publicada no Diário Oficial da União (DOU) em 10 de março do mesmo, após sanção do Presidente Lula.

Um minucioso exame nas páginas oficiais da Câmara e do Senado Federal sobre a movimentação do PL 433/2003 até a sua transformação em Lei 11.645/2008, permite confirmar que a aprovação de uma norma jurídica não é fácil. As duas Casas de leis do Brasil são arenas políticas que envolvem disputas de várias ordens. Mas em relação à aprovação das leis 10.639/2003 e 11.645/2008 avaliamos que o contexto político e institucional favoreceu ambas. Mas isso não diminui sua importância. Entendo essa trajetória como uma etapa importante no processo na medida em que, por meio de uma linguagem liberal, o Direito assegurou uma politica de ação afirmativa que busca reparar lacunas curriculares.

O acompanhamento da Lei 11.645/2008 por parte de um significativo grupo de docentes e intelectuais indígenas na atualidade constitui a meu ver, um terceiro aspecto onde a temática ganha novas dimensões.

Figura 4 - Tematizando os Povos Indígenas na Escola.
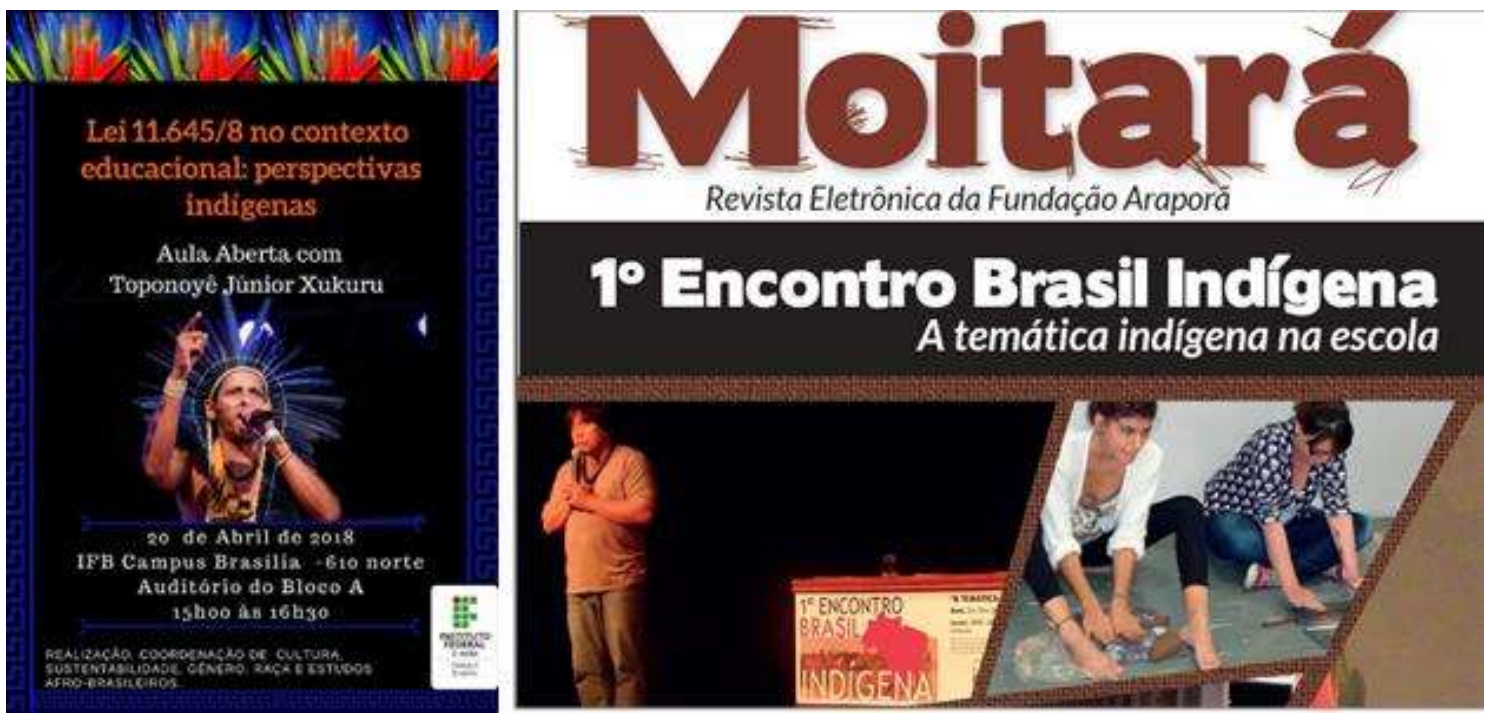

Fonte: Instituto Federal de Brasília (2018). Fundação Araporã (2014).

Em diferentes fóruns o estudo da História e das culturas indígenas na escola tem sido reivindicado: "Na Educação, [...] que seja aplicada imediatamente [a] Lei 11.645, que trata da obrigatoriedade do ensino da diversidade nas escolas". (APIB, 2013, p. 1). Aos poucos o protagonismo dos Povos Originários vem ganhando visibilidade extraordinária quanto ao seu cumprimento.

Assim, as vozes indígenas têm ecoado cada vez mais no país. Em Rondônia temos acompanhado um pouco de suas percepções em atividades acadêmicas: "Penso que a Lei 11.645/2008 é muito importante, porque o não-indígena não conhece nada de índio. Muitas vezes pensam que os indígenas não têm conhecimentos, não têm saber, [...]. Mas na verdade mesmo o indígena que não sabe ler e escrever, [...] tem conhecimentos" (PEME ARARA, 2016, p. 997). Outra perspectiva 
apontada é que a Lei $11.645 / 2008$ significa uma porta aberta ao diálogo intercultural, evidência sublinhada pelo pesquisador e professor Joaton Pagater Suruí: "essa Lei se tornou mais importante, porque abriu oportunidade para os povos indígenas, garante que [...] coloquem suas necessidades atuais, suas formas de pensar" (FRAGA, 2018, p. 59).

Avalio que a mediação de outrora - pesquisadores (as), assessores (as) não-indígenas, ainda tem um lugar, porém mais discreto. É um contexto tenso, mas penso que a contribuição de aliados e aliadas virá a partir de um caminhar juntos, de negociar espaços, pois: "A prática da liberdade só encontrará adequada expressão numa pedagogia em que o oprimido tenha condições de, reflexivamente, descobrir-se e conquistarse como sujeito de sua própria destinação histórica". (FIORI, 1987, p. 6).

A sustentação teórica que contribuiu e contribui para iniciativas como a Lei 11645/2008, representa o quarto aspecto. Significa um conjunto explicativo traduzido nas Teorias críticas (FREIRE, 1987) e póscríticas do Currículo (SILVA, 2011 ), os Estudos Culturais (HALL, 2013 ), a Pedagogia Decolonial (WALSH, 2009) e os Estudos Pós-Coloniais (BHABHA, 2013), dentre outros:

a Lei $11645 / 2008$ decorre de muitas influências de cunho teórico que contribuíram para o seu surgimento, dentre as quais citamos: as Teorias Pós-Críticas do Currículo que ancoradas no pensamento pós-moderno problematizaram os padrões da modernidade, representados pelos termos - branco, masculino, heterossexual e cristão, possibilitando visibilidade às diversidades étnicas, raciais, femininas, sexuais e religiosas; os Estudos Culturais e pós-colonialistas expressos nos conceitos de $[\ldots]$ interculturalidade $[\ldots]$; as contribuições da História Cultural [...] que investiga mentalidades e práticas culturais e suas relações com os mecanismos de dominação e de exploração entre os diferentes grupos sociais (NEVES, 2013b, p. 3).

Além da participação indígena nos rumos do estudo e das culturas no ambiente escolar, há outro elemento importante que tem relação direta com A Questão Indígena na Sala de Aula: subsídios para professores de $1^{\circ}$ e $2^{\circ}$ graus (LOPES DA SILVA, 1987). Refiro-me às modificações que vêm ocorrendo no Programa Nacional do Livro e do Material Didático (PNLD). Talvez uma luz no fim do túnel... É o quinto aspecto que evidencia que a Lei $11645 / 2008$ constitui mais que uma norma jurídica no cenário educacional brasileiro, referente aos povos indígenas no currículo escolar. É uma política pública.

Desde 2007, o Edital PNLD estabeleceu critérios éticos para qualificação de obras analisadas. Será selecionado aquele livro que: "promova positivamente a imagem [...] das etnias indígenas brasileiras, [...] trabalhos e profissões e espaços de poder; [...] a cultura [...], visibilidade aos seus valores, tradições, organizações e saberes sociocientíficos" (BRASIL, 2007, p. 35). 
Vale salientar que embora a Lei 11.645 tenha sido publicada apenas em 2008, essa normativa estava em tramitação desde 2003, através do Projeto de Lei 433/2003 de autoria da deputada Mariângela Duarte (PT) como já informamos neste trabalho. Significa afirmar que, possivelmente em função do conhecimento desta tramitação, de outras políticas de visibilidade das etnias brasileiras, do contexto politico favorável, o Edital ${ }^{8}$ 2007 incluiu em seus critérios a preocupação com representação de imagens indígenas mais próximas das realidades dos povos, conforme discutiremos abaixo.

A figura 7 (sete) é composta de duas imagens. A de cor azul é um cartaz informando as famílias sua concepção de Povos Indígenas. Uma representação que não reforça estereótipos, não trabalha com a data do dia 19 de abril. De forma processual, reconhece a diversidade de povos e modos de vida. Informa que os espaços de moradia e atuação indígena podem ser na floresta e na cidade e que além de caçar e pescar, os indígenas atualmente podem desenvolver atividades em ambientes escolares, hospitalares, dentre outras informações, conforme preconiza a Lei $11.645 / 2008$.

Figura 5 - Luz no fim do túnel?

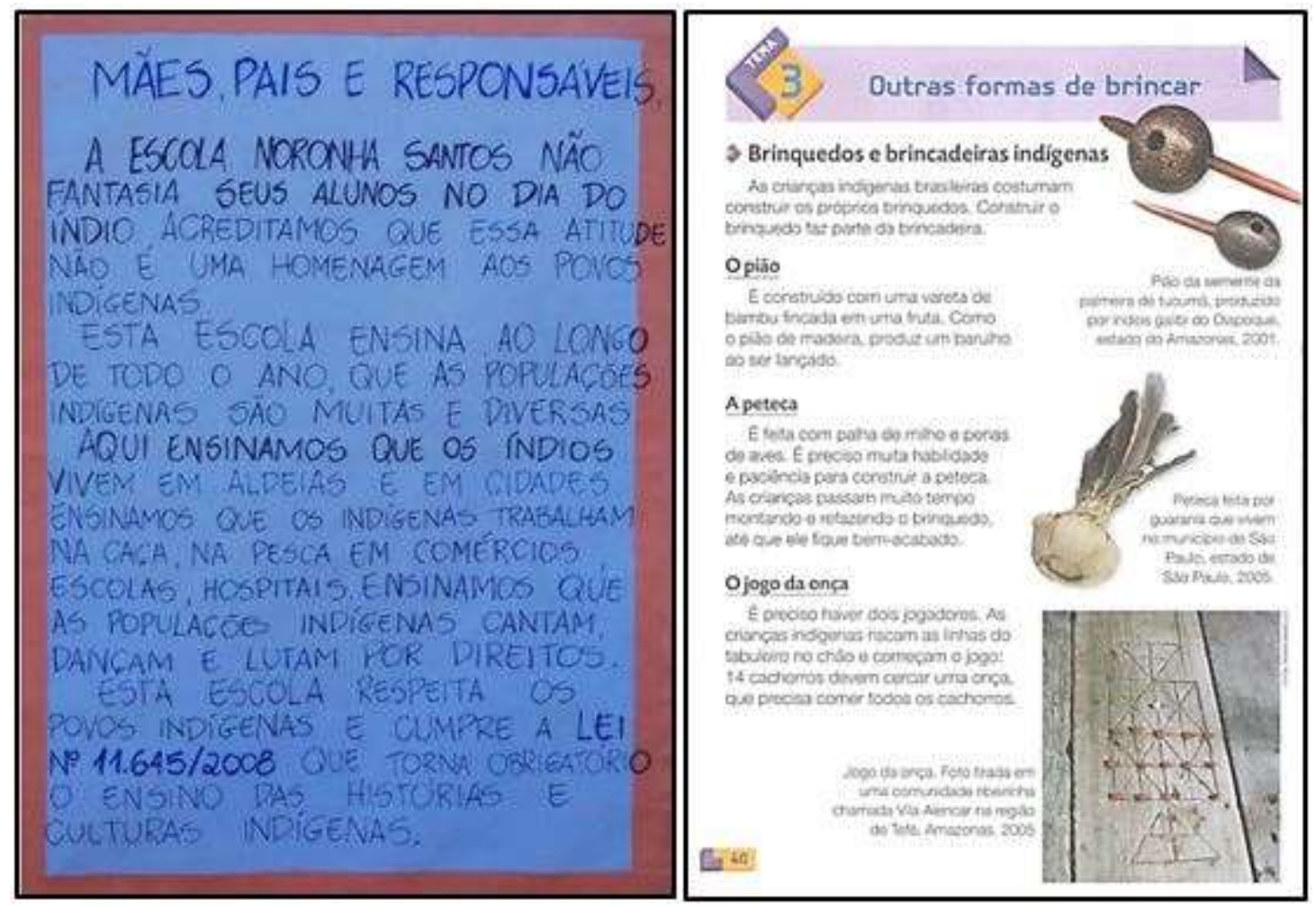

Fonte: Cartaz Facebook Escola Noronha. Projeto Buriti, $2^{\circ}$ ano - Ens. Fund.

A outra imagem é a página de um livro didático da área de História, adotado pela rede municipal de Ji-Paraná, Rondônia, para turmas do $2^{\circ}$

${ }^{8}$ É importante acrescentar que não conseguimos localizar os Editais anteriores. 
ano do ensino fundamental. As atividades apresentadas permitem inferir que há mudanças à vista, a favor da temática indígena na escola.

O conteúdo temático é: "Outras formas de brincar", difundindo alguns brinquedos e brincadeiras indígenas - pião e a peteca dos povos Galibi do Oiapoque, estado do Amazonas, e os Guarani de São Paulo. O assunto pode interessar as crianças considerando a faixa etária da turma. A pergunta principal é: o que as crianças não-indígenas podem aprender com esse conteúdo?

Talvez possam saber como é o modo de brincar de crianças indígenas de dois lugares diferentes e como são confeccionados. A qualidade das imagens contribui para uma melhor percepção de como são os objetos, assim como a localização das etnias e o tempo do registro, importantes elementos que atestam a contemporaneidade dos Povos Indígenas.

A perspectiva adotada no livro é a de estudar os conteúdos por meio de temas, uma forma de dispensar o viés cronológico e provocar deslocamentos na discussão curricular. No entanto, como sugestão, entendo que seria adequado apresentar exemplos de brinquedos comercializados, que também são comuns em algumas aldeias indígenas.

Avalio que alterações como essas não ocorrem por acaso. Há um encadeamento de ações: inquietações indígenas sobre a identidade representada nos materiais escolares; estudos e publicações com a temática indígena na rede escolar. Há a elaboração, aprovação e publicação da Lei 11.645/2008 que estabeleceu a obrigatoriedade do estudo da História e cultura indígena na escola, o PNLD que define os critérios em Edital que determinam que livro pode ser selecionado e os mecanismos de acompanhamento, investigação e extensão com vistas ao seu aperfeiçoamento.

Assim, retornando ao poeta, é possível compreender e até concordar que "os lírios não nascem da lei". Talvez não possamos instituir a interculturalidade por decreto ou por uma emenda à Lei de Diretrizes e Bases da Educação Nacional, no 9394/1996, caso da Lei 11.645/2008. Mas penso que a legislação pode constituir um item importante para a viabilização de uma consistente política pública de inclusão.

Inspirada em Aracy Lopes da Silva, nomeamos um conjunto de aspectos que evidenciam a fecundidade da temática indígena na sala de aula, ou do estudo da História e culturas indígenas, como identifica a Lei 11.645/2008, ou ainda como interpretamos na Linha de Pesquisa Antropologia Etnopedagógica e Currículo - possibilidades de aprendizagens interculturais.

Embora não seja muito propensa a fazer homenagens, penso que talvez minha proposição encontre eco. A Lei 9394/2008 recebeu o nome de Lei Darci Ribeiro pelo envolvimento e compromisso do antropólogo e seu defensor. Avalio que com a Lei 11.645/2008 não poderia ser diferente: Lei Aracy Lopes da Silva. 


\section{Considerações Finais}

A escrita deste texto foi mobilizada a partir dos textos de Aracy Lopes da Silva sobre a questão indígena na escola. Uma homenagem reflexiva. Não a conheci, mas ao ler textos de pessoas que conviveram com a professora, em alguns trechos, tudo parecia muito familiar. O que eu enxerguei foi uma antropóloga-educadora, uma pesquisadoraextensionista. Para Aracy não bastava pesquisar: era necessário intervir. Educação era um puro ato político como ensina Paulo Freire.

Em tempos onde o absurdo vira banalidade e em que as populações indígenas e grupos mais expostos sofrem ataques permanentes de forças conservadoras orientadas pela brutalidade do capital, é preciso produzir e visibilizar epistemes. É preciso compreender e apostar no Bem Viver.

Nesta direção, este trabalho foi pensado e produzido no contexto político atual que cada vez mais nos pressiona a trilhar caminhos já conhecidos e descartados: terra plana, marxismo cultural, movimento antivacina, Paulo Freire inimigo da Educação e outros. E isso implica gastar um tempo precioso. Tempo que talvez nem tenhamos.

Em meio a isso, surgiu o propósito de revisitar Aracy, especificamente o seu texto de 1984, republicado em 1987. O artigo foi o fio da meada que permitiu tecer um diálogo sobre a trajetória da temática indígena na escola até o momento. De constatar que a mudança cultural é lenta, pois muitas de suas preocupações são atuais. Ainda há muita discriminação e preconceito contra as identidades indígenas. A saúde nas aldeias e na cidade é um quadro de precarização e os territórios indígenas sofrem ameaças e saques permanentes.

E como naquele tempo, nos resta a educação crítica e com ela a tarefa de formar mentes que possam aprender e ensinar interculturalidade crítica. Para isso, é necessário tensionar o currículo colonial monocultural que reservou apenas um dia para "comemorar" os Povos Indígenas. Uma lembrança cristalizada que teima em negar suas contribuições e existências na contemporaneidade. Significa compreender que as lutas na arena curricular continuam.

Nesta construção, a publicação da Lei $11.645 / 2008$ representou o acúmulo de um debate histórico pautado, sobretudo, nas preocupações humanistas, na insistência por um mundo em que todos e todas possam ter um lugar de Bem Viver. Temos muitos problemas, mas temos muitas propostas de enfrentamento a estes problemas.

A referida discussão foi produzida a partir da Linha de Pesquisa Antropologia Etnopedagógica e Currículo, vinculada ao Grupo de Pesquisa em Educação na Amazônia (GPEA) no segundo semestre de 2019, em Ji-Paraná, estado de Rondônia. A proposta é de natureza qualitativa e foi possível a partir da pesquisa bibliográfica e de levantamentos de dados documentais em arquivos digitais.

Avaliamos que o trabalho de Aracy Lopes da Silva possibilitou uma articulação fundamental entre a Antropologia e a Pedagogia no âmbito das aprendizagens interculturais indígenas. Sua preocupação era investir tempo e conhecimento na formação docente urbana de modo que 
pudesse contribuir na construção e visibilização de um currículo acolhedor das diferenças.

Enquanto a preocupação da maioria dos profissionais da Antropologia e da Linguística se dirigia à produção de materiais didáticos para as escolas indígenas (e isso era necessário), Aracy se incomodava e mobilizava pessoas para produzir a crítica sobre os livros que chegavam a escola urbana, bem como para propor sugestões que viabilizassem uma melhor compreensão sobre as sociedades indígenas. Seu movimento ia na direção da aldeia, mas também na direção da cidade.

As ações possibilitadas através de publicações significaram uma efetiva contribuição para a episteme intercultural, propondo respostas para a inquietação provocada pelas representações coloniais que a escola teima em reeditar acerca das imagens indígenas. Certamente gestos dos anos 1970-1980 culminaram com a publicação da Lei 11.645/2008 no que se refere à inserção do estudo das culturas originárias no currículo.

Concordamos com o poeta Drummond e com o professor Darci Secchi (UFMT): é verdade que as leis por si só não bastam. Mas com as políticas públicas talvez possamos andar um pouco mais e, quem sabe, se aproximar dos lírios. As imagens nos livros didáticos contemporâneos permitem estas afirmações. Essa evidência, resultante dos conhecimentos construídos na Linha de Pesquisa Antropologia Etnopedagógica $e$ Currículo (GPEA) e da percepção das pesquisas e publicações atuais sobre a temática indígena no ambiente escolar - repercussões dos trabalhos da antropóloga-educadora - nos impulsiona a propor um nome para a Lei $n^{0}$ $11.645 / 2008$, Lei Aracy Lopes da Silva. 


\section{Referências bibliográficas}

ACHINTE, Adolfo Albán. Epistemes "Otras": ¿Epistemes Disruptivas? Kula, Antropólogos del Atlántico Sur, n. 6, p. 22 - 34, abril, 2012. Disponível em: http://www.revistakula.com.ar/numeros-anteriores/numero-6/kula6_2_alban_achinte/ Acesso em: 13 dez. 2019.

ANDRADE, Carlos Drummond. Nosso tempo. In: C. D. Andrade. A rosa do povo. 21. ed. Rio de Janeiro: Record, 2000.

BOGDAN, Robert; BIKLEN, Sari. Investigação qualitativa em Educação: fundamentos, métodos e técnicas. In: Investigação qualitativa em educação. Portugal: Porto Editora, 1994, p. 15-80.

BHABHA, Homi K. O local da cultura. Belo Horizonte: Ed. da UFMG, 1998.

BRASIL. Lei 11.645/2008. Altera a Lei no 9.394/1996. Inclui no currículo oficial da rede de ensino a obrigatoriedade da temática "História e Cultura Afro-Brasileira e Indígena. Disponível em: $\quad$ http://www.planalto.gov.br/ccivil_03/Ato20072010/2008/Lei/L11645.htm Acesso em: 21 dez. 2019.

BRASIL. Parecer CNE/CEB No 14/2015. Diretrizes Operacionais para a implementação da história e das culturas dos povos indígenas na Educação Básica, em decorrência da Lei no 11.645/2008. Disponível em: http://portal.mec.gov.br/index.php? Acesso em: 22 abr. 2018.

BRASIL. Câmara dos Deputados. PL 433/2003. Autora: Deputada Federal Mariângela Duarte - PT/SP. Situação: Transformado na Lei Ordinária 11645/2008.

Disponível em: https://www.camara.leg.br/proposicoesWeb/fichadetramitacao?idProposicao=107240 Acesso em: 10 dez. 2019.

BRASIL. Câmara dos Deputados. Parecer 1.07.2003. Relatora: Deputada Federal Fátima Bezerra - PT/RN. Situação: Transformado na Lei Ordinária 11645/2008. Disponível em: https://www.camara.leg.br/proposicoesWeb/fichadetramitacao?idProposicao $=107240$ Acesso em: 10 dez. 2019.

BRASIL. Senado Federal. Parecer 22/2007. Relatora: Senadora Federal Fátima Cleide PT/RO. Situação: Transformado na Lei Ordinária 11645/2008. Disponível em: https://www.camara.leg.br/proposicoesWeb/fichadetramitacao?idProposicao $=107240$ Acesso em: 10 dez. 2019.

BRASIL. PNLD/2007. Edital de convocação para inscrição no processo de avaliação e seleção de obras didáticas a serem incluídas no guia de livros didáticos de $1^{\mathrm{a}}$ a $4^{\mathrm{a}}$ série do PNLD/2007.

Disponível em: https://cchla.ufrn.br/pnld/wp-content/uploads/edital_pnld_2007-4.pdf Acesso em: 10 dez. 2019. 
Espaço Ameríndio

CAMPUS recebe aula aberta. Instituto Federal de Brasília (IFB). 17.04.2018. Disponível em: https://www.ifb.edu.br/brasilia/17141-campus-recebe-aula-aberta-com-liderancaindigena Acesso 12.12.2019.

CUNHA, Maria Isabel da. Conta-me agora! As narrativas como alternativas pedagógicas na pesquisa e no ensino. Revista da Faculdade de Educação. v. 23 n. 1-2 São Paulo Jan./Dez. 1997.

ECO, Umberto; BONAZZI, Marisa. Mentiras que parecem verdades. 6 ed. São Paulo: Summus, 1980.

EXPLORAÇÃO e miséria. A cultura indígena acabando aos poucos. FM 29.04.1977. Armazém Memória. Coleção de recortes de jornal sobre a política indigenistalColeção CIMI-MS $\backslash 1977 . \quad$ Disponível em: http://www.docvirt.com/docreader.net/DocReader.aspx?bib=HemeroIndioRecortes\&pes $\mathrm{q}=$ coelho Acesso em: $21 \mathrm{dez} .2019$.

FUNDAÇÃO Araporã. Moitará. $1^{\circ}$ Encontro Brasil Indígena. 26.09.2013. Disponível em: http://fundacaoarapora.org.br/moitara/edicao01/ Acesso em: 10 dez. 2019.

FRAGA, Jaine Teixeira da. "A partir delas e com elas": Perspectivas indígenas Paiter Surui e Karo Arara sobre a Lei 11.645/2008, História e culturas indígenas na escola do "branco" na Amazônia. 2018. Trabalho de Conclusão de Curso (Licenciatura em Pedagogia) - Universidade Federal de Rondônia - UNIR, Campus Urupá, Ji-Paraná, 2008.

FREIRE, Paulo. Pedagogia do Oprimido. 17. ed. Rio de Janeiro: Paz e Terra, 1987.

FREIRE, Paulo. Pedagogia da Esperança: um reencontro com a Pedagogia do Oprimido. São Paulo: Paz e Terra, 1997.

FIORI, Ernani Maria. Aprender a dizer a sua palavra. In: FREIRE, Paulo. Pedagogia do oprimido. Rio de Janeiro: Paz e Terra, 1987.

GRUPIONI, Luís Donisete Benzi. Aracy Lopes da Silva. Revista de Antropologia, São Paulo, v. 43, n. 2, p. 17-20, 2000. Disponível em: http://www.revistas.usp.br/ra/issue/view/2036 Acesso em: $21 \mathrm{dez} .2019$.

HALL, Stuart. A Identidade Cultural na pós-modernidade. 11 ed. Rio de Janeiro: Editora DP\&A, 2006.

LAKATOS, Eva Maria, MARCONI, Marina de Andrade. Procedimentos Didáticos. In: Fundamentos de Metodologia Científica. 5 ed. São Paulo: Atlas.2003.

LOPES DA SILVA, Aracy. A questão indígena na sala de aula. [s.1.], 1984. 47-51 p. 47 (Escola Municipal). Disponível em:

http://biblioteca.funai.gov.br/media/pdf/Folheto09/FO-CX-09-522-89.PDF Acesso em: 15 nov. 2019.

LOPES DA SILVA, Aracy (org). A Questão Indígena na Sala de Aula: subsídios para 
professores de $\mathbf{1}^{\mathbf{0}}$ e $\mathbf{2}^{\mathbf{0}}$ graus. São Paulo: Brasiliense, 1987.

LOPES DA SILVA, Aracy e GRUPIONI, Luis Donisete (orgs). A Temática Indígena na Escola: novos subsídios para professores de $1^{\circ}$ e $2^{\circ}$ graus. 2. ed. São Paulo: Global; Brasília: MEC: MARI: UNESCO, 1995.

LISPECTOR, Clarice. Felicidade Clandestina. In: Felicidade Clandestina. Rio de Janeiro: Ed. Rocco, 1998.

NEVES, Josélia Gomes. Povos Indígenas em escolas urbanas da Amazônia: a reedição do contato? Revista P@rtes, São Paulo, 2013. Disponível em: http://www.partes.com.br/2013/05/15/curriculo-intercultural/

Acesso em: 21 dez. 2019.

NEVES, Josélia Gomes. Currículo Intercultural: processo de aplicação da Lei 11.645 /2008 nas escolas públicas da Amazônia. Revista P@rtes: SP. 2013b. Disponível em: http://www.partes.com.br/2013/05/15/curriculo-intercultural/. Acesso em: 15 jul. de 2016.

NOSELLA, Maria de Lourdes Chagas Deiró. As Belas Mentiras: a ideologia subjacente aos textos didáticos. 8. ed. São Paulo: Moraes, 1978.

PEME ARARA. Marli. Significado da Lei 11.645/2008 na perspectiva de uma professora e pesquisadora indígena. Anais IX SED, Ji-Paraná/ RO, 2016. Disponível em: http://www.sed.unir.br/downloads/6116 anais_do_ix_sed_2016_vol._1_final.pdf

Acesso em: 19 dez. 2019.

RIBEIRO, Berta G. A Contribuição dos Povos Indígenas à Cultura Brasileira. In.: . LOPES DA SILVA, Aracy; GRUPIONI, Luís Donizete Benzi. A temática indígena na escola: novos subsídios para professores de $1^{\circ}$ e $2^{\circ}$ graus. Brasília, MEC/MARI/UNESCO, 1995.

SANTOMÉ, Jurjo Torres. Currículo escolar e justiça social: o cavalo de Tróia da educação. Porto Alegre: Penso, 2013.

SILVA, Tomas Tadeu. Documentos de identidade: uma introdução as teorias do currículo. 3. ed. Belo Horizonte: Autêntica, 2011.

TASSINARI, Antonella. Maria Aracy de Pádua Lopes da Silva (1949-2001). Anuário Antropológico/2000-2001, Rio de Janeiro: Tempo Brasileiro, 2003.

Disponível

em:

http://www.dan.unb.br/images/pdf/anuario antropologico/Separatas\%202000-

2001/2000-2001_antonellatassinari.pdf Acesso em: 21 dez. 2019.

TEIXEIRA, Raquel F. A. As línguas indígenas no Brasil. In: LOPES DA SILVA, Aracy e GRUPIONI, Luis Donisete (orgs). A Temática Indígena na Escola: novos subsídios para professores de $\mathbf{1}^{\mathbf{0}}$ e $\mathbf{2}^{\mathbf{o}}$ graus. 2. ed. São Paulo: Global; Brasília: MEC: MARI: UNESCO, 1995. 
Espaço Ameríndio

TELLES, Norma. Resenha: A questão indígena na sala de aula. Aracy Lopes da Silva. (Org.). Brasiliense, 1987, 253 p. Caderno de Pesquisa, São Paulo, n. 62, p. 79-80, agosto 1987.

Disponível em: https://dialnet.unirioja.es/servlet/articulo?codigo=6209249 Acesso em: 21 dez. 2019.

VIDAL, Lux. Homenagem a Aracy Lopes da Silva (1949 - 2000). Revista de Antropologia, São Paulo, v. 43, n. 2, p. 11-16, 2000. Disponível em: http://www.revistas.usp.br/ra/issue/view/2036 Acesso em: 12 dez. 2019.

WALSH, Catherine. Interculturalidad critica y (de) colonialidad: Ensayos desde Abya Yala. Quito: Ediciones Abya-Yala, 2012.

WALSH, Catherine. Interculturalidade crítica e pedagogia decolonial: in-surgir, re-existir e re-viver. In. CANDAU, Vera Maria (Org.). Educação intercultural na América Latina: entre concepções, tensões e propostas. Rio de Janeiro: 7 Letras, 2009. 